\title{
ETHNOTHERAPEUTIC EVALUATION AND ANTI-NUTRIENT CONTENT OF COMMON PLANTS USED FOR MANAGEMENT OF KIDNEY AND LIVER DISORDERS IN ODEDA COMMUNITIES, OGUN STATE, NIGERIA
}

\author{
${ }^{1}$ Kadiri, M, ${ }^{2}$ Ojewumi, A.W, ${ }^{3}$ Bada, I.O \\ Department of Pure and Applied Botany, Federal University of Agriculture, Abeokuta, Ogun State Nigeria \\ *Corresponding Author's E-mail: mukailakadiri@yahoo.com
}

Received 16 Feb 2015; Review Completed 26 March 2015; Accepted 08 April 2015, Available online 15 May 2015

\begin{abstract}
A survey study was carried out on plants used to manage kidney and liver diseases in Odeda Local Government Area, Ogun State, Nigeria. A total of hundred (100) questionnaire were administered using stratified sampling method on traditional herbal practitioners. Ethnobotanical data such as, plants and plant parts and methods of extraction used were sought. Anti-nutrients of the frequently mentioned plants were also evaluated. Data were subjected to Analysis of variance (ANOVA) with probability set at $\mathrm{p}<0.05$ and descriptive statistics. Results revealed that $55.5 \%$ of the respondents were females while $45.5 \%$ were males. Largest percentage (47.9\%) were between the ages 41-60years. Twenty six 26(26.0\%) of the respondents were herbalists, $34(34.0 \%)$ were herb sellers, 21(21.0\%) were Traditional practitioners while 19 (19.0\%) were Traditional practitioners and herb sellers. Twenty three (23) of the respondents had 1-5years, 35 had 6-10 years while 42 of them had being in the herbal profession for more than 10 years. Seventy four percent (74\%) of plants collated during this study were available both in home garden and markets. Fifty 50 plants species belonging to 37 families were reported being used to manage kidney and liver diseases. Malvaceae and meliaceae were the most frequently mentioned families. Largest number of plants $20(40 \%)$ collated were trees, followed by herbs $19(38 \%)$ while vegetable $1(2 \%)$ was vegetable. The most commonly used plants part were Leaves, barks roots, fruits, seeds bulbs and combination of any of these parts. Decoction, soaking, infusion, grinding, strong heating paste and combination(s) of any of these methods were employed for preparing herbal remedies of these diseases. No significant difference $(\mathrm{P}>0.05)$ was recorded in the phytate content of Khaya ivorensis and Kigelia africana leaves. Similar observation was recorded in the oxalate and cyanide content of Chasmantheran dependens and Kigelia africana leaves.. Polyphenol and tannins were significantly different across the leaves of plants under this investigation. No significantly different $(\mathrm{P}>0.05)$ was recorded in the quantity of phytate present in Chasmantheran dependens and Kigelia africana, oxalate of Chasmantheran dependens, Kigelia africana and Azadirachta indica, and cyanide in root of the plants. Highest phytate (13.00) was recorded in Azadirachta indica, oxalate (12.33), Polyphenol (9.00) and cyanide (4.33) in Ficus exasperate while tannins (16.00) were recorded in the leaves of Chasmantheran dependens.
\end{abstract}

Keywords: Ethnobotanical data , Anti-nutrient content, Kidney and Liver disorders

\section{INTRODUCTION}

The advent of modernization and technological development has given rise to increased risk of kidney and liver diseases among humans. The need to control or cure the diseases resulted to proliferation of synthetic drugs (Swati and Kanungo, 2013). Despite diverse advances in modern medicine, there is till significant revitalization of interest with respect to medicine and traditional pharmacopoeia. Plants are important sources of therapeutic drugs and play beneficial roles in the survival of the local communities including Odeda. Plants characterized several therapeutic potentials useful for manufacture of natural and affordable herbal drugs (Al-Adhroey $e t$ al., 2010) with less side effects compare to allopathic medicines Irum et al., 2014.
The use of synthetic drugs leads to the problems of side effects, ill effects, and complications of organs such as lungs and kidneys. Liver and kidney disorders are some of the common health problems which affect both old. It is a common and important cause of illness and death.

Therefore, documentation flora of any community for conservation and sustainable use is important not only for food but also for management of diseases.

Despite the array of medicinal flora of Odeda, no research has been conducted on the survey of plants having medicinal potential of managing kidney and liver diseases in the communities.

Therefore, the aim of this study was to systematically collect information about the usage of plants in human 
therapy In the light of this, this study aimed to identify, collate and characterize plants commonly used to manage liver and kidney problems among people of Odeda and its environs.

\section{MATERIALS AND METHODS}

\section{STUDY AREA}

The study was carried out in Odeda Local Government. Odeda Local Government Area is located on Latitude $70 \mathrm{~N}$ and Longitude $30 \mathrm{E}$. It occupies an area of $1,658 \mathrm{~km} 2$ with an estimated population of 109,449 (National Population Commission, 2006). The economy of the town is based on agriculture, informal services and small scale (cottage) industries. Odeda is characterized by tropical climate marked with dry and wet seasons distinguished by moist south westerly monsoon winds which always result into heavy rainfall between March and October.

There are about $25-30$ semi-urban areas, 860 villages and hamlets in the local government area. Government establishments such as Federal University of Agriculture, Abeokuta, Federal college of Education, Osiele, Ogun- Oshun River Basin Development Authority and State Headquarters of Nigeria Police Eleweran are located in Odeda Local Government Area. Olodo, Olugbo, Kila, Alabata and Osiele are the major markets located in the study areas. Politically, Odeda Local Government Area is divided into ten (10) Electoral Wards, viz-Odeda, Itesi, Olodo, Alagbagba, Ilugun, Osiele, Obantoko, Alabata, Obete, Opeji. Eba, Fufu, Lafun (White Amala), Pounded yam, Plantain are food items associated with people in the area.

Determination of Anti-nutrient content of the most frequently mentioned plants

The anti-nutrient contents of the most frequently mentioned plants were conducted according to the method described by Sowofora et al., 1993.

\section{Questionnaire administration and data collection}

\section{Informed consent}

The purpose of the study was explained to the local traditional practitioners, herb sellers, community leaders, market-head leaders and herbal shop owners in the town. Consent to was given by the head of traditional herb practitioners and community leaders. Informed consent was obtained from all the respondents. An approval for the study was obtained from market leaders and traditional heads of the communities in which the markets were located.

\section{Questionnaire administration}

One hundred(100) structured and validated questionnaire were administered randomly to traditional herbal practitioners and herb sellers, to obtain information on commonly used herbs, names of plants, parts used, methods of herbal preparation, route of administration, mode of administration, dosage measurement and duration of usage. The questionnaires were administered by purposeful sampling method.
Table 2

\begin{tabular}{|c|c|}
\hline \multicolumn{2}{|c|}{ Reliability Statistics } \\
\hline Cronbach's Alpha $^{\mathrm{a}}$ & Number of Items \\
\hline 0.86 & 20 \\
\hline
\end{tabular}

\section{Quantitative phytochemical screening of leaves and} roots of most frequently mentioned plants

Phytochemical contents such as phytate, oxalate, Polyphenol, Cyanide $\mathrm{mg} / \mathrm{kg}$ and Tannins

of leaves and roots of the most frequently mentioned plant were carried out according Sofowora et al., 1993

\section{Statistical Analysis}

Data were subjected to Analysis of variance (ANOVA) and means were by Duncan's multiple ranges Test (DMRT) at $\mathrm{P}<0.05$.

\section{RESULTS}

A total of 100 randomly selected respondents were interviewed out of which $55.5 \%$ were females while $45.5 \%$ were males. Majority of the respondents $(47.9 \%)$ were between the ages 41-60years, followed by people who were more than 60years $(28.1 \%)$ while least $(2.1 \%)$ of the respondents were recorded at age group 1-20years.

Thirty two percent $(32.0 \%)$ of the respondents were Christians, $30.0 \%$ were Muslim while $38.0 \%$ practiced traditional religion. Majority of the respondents were educated as indicated by 84 percent. $26(26.0 \%)$ of the respondents were herbalists, $34(34.0 \%)$ were herb sellers, 21(21.0\%) were Traditional practitioners while $19(19.0 \%)$ were Traditional practitioners and herb sellers (Figure 1).Years (s) of herbal practice played significant roles in the acquisition of herbal knowledge. 23 out of the respondents had 1-5years, 35 had 6-10 years while 42 of them had being in the herbal profession for more than 10 years (Figure 2). Fifty 50 plants species belonging to 37 families were reported being used to manage kidney and liver diseases. Malvaceae and meliaceae were the most frequently mentioned families (Table 2).

Seventy four (74\%) of plants collated during this study were reported to be available mostly at home garden and markets (Figure 3). Largest number of plants $20(40 \%)$ collated during this study were trees, followed by herbs $19(38 \%)$ while vegetable $1(2 \%)$ was vegetable (Figure 4).

This study provides baseline ethnobotanical information on the use of plants by Odeda community herbal healers to treat liver and kidney diseases.

The most commonly used plants part reported being used were leaves, barks, roots, fruits, seeds bulbs and combination of any of these parts (Figure 5). Different methods of preparations such as decoction, soaking, infusion, grinding, strong heating paste and combination(s) of any of these methods were employed for preparing herbal remedies of these 
diseases. Decoction (45\%) was the most preferred (Figure 6) usually with water as indicated by (Figure 7).

No significant different $(\mathrm{P}>0.05)$ was recorded in the phytate contentment of Khaya ivorensis and Kigelia africana leaves. Similar observation was recorded in the oxalate and cyanide content of Chasmantheran dependens and Kigelia africana leaves. This effect varied significantly $(\mathrm{P}<0.05)$ compared with oxalate determined in the leaves of Azadirachta indica and Ficus exasperate. Polyphenol and tannins contents were significantly different $(p<0.05)$ across the leaves of plants under this investigation. Also, in the roots of the plants, no significantly different $(\mathrm{P}>0.05)$ was recorded in the quantity of phytate present in Chasmantheran dependens and Kigelia africana, oxalate of Chasmantheran dependens, Kigelia Africana and Azadirachta indica, and cyanide in root of the plants except Kigelia Africana. Similar amount of tannin was recorded in Khaya ivorensis and Kigelia africana as also observed in Azadirachta indica and Ficus exasperate. Highest phytate 13.00) was recorded in Azadirachta indica, oxalate (12.33), Polyphenol (9.00) and cyanide (4.33) were recorded in Ficus exasperate while tannins (16.00) were recorded in the leaves of Chasmantheran dependens (Table 4). This study indicates that the quantity of anti nutrient was higher in the leaves of the plants under consideration roots.

Table 1: Socio- Economic Characteristics of Respondents of Odeda local Government Area

\begin{tabular}{|l|l|l|l|}
\hline Variables & Frequency & \% Frequency & Mode \\
\hline SEX & & & \\
\hline Male & 45 & 45.5 & \\
\hline Female & 55 & 55.5 & Female \\
\hline Age & & & \\
\hline 1-20years & 2 & 2.1 & \\
\hline 21-40years & 21 & 21.9 & \\
\hline 41-60years & 46 & 47.9 & $41-60$ years \\
\hline More than 60years and above & 27 & 28.1 & \\
\hline RELIGIONS & & & \\
\hline Christianity & 32 & 32.0 & \\
\hline Islam & 30 & 30.0 & \\
\hline Traditional & 38 & 38.0 & Traditional \\
\hline Educational status & & & \\
\hline Primary & 50 & 50.0 & Primary \\
\hline Secondary & 30 & 30.0 & \\
\hline Tertiary & 4 & 4.0 & \\
\hline Non formal & 16 & 16.0 & \\
\hline
\end{tabular}

Table 2: Plants commonly used for managing kidney and liver diseases

\begin{tabular}{|l|l|l|l|l|l|}
\hline BOTANICAL NAMES & FAMILY & $\begin{array}{l}\text { LOCAL } \\
\text { NAMES }\end{array}$ & $\begin{array}{l}\text { COMMON } \\
\text { NAMES }\end{array}$ & HABIT & PART USED \\
\hline Adansonia digitata & Bombacaceae & Ose & Baobab & Tree & Leaves, barks \\
\hline Aframomum melegueta & Zingeberaceae & Atare & Alligator pepper & Herb & Fruits \\
\hline Allium ascalonicum & Liliaceae & $\begin{array}{l}\text { Alubosa } \\
\text { elewe }\end{array}$ & Onion & Herb & Bulbs \\
\hline Allium cepa & Liliaceae & $\begin{array}{l}\text { Alubosa } \\
\text { onisu }\end{array}$ & Onion & Herb & Bulbs \\
\hline Anacadium occidentale & Anacadiace & Chasu & Cashew & Tree & Leaves, Barks \\
\hline Annanas comosus & Bromeliaceae & Ope oyinbo & Pineapple & Herb & Whole plant \\
\hline Arachis hypogaea & Leguminose & Epa & Groundnut & Shrub & Leaves \\
\hline Azadirachta indica & Meliaceae & Dongoyaro & Neem tree & Tree & Leaves \\
\hline Bidens Pilosa & Compositae & Abere & Black jar & Herb & Whole plant \\
\hline Carica papaya & Caricaceae & Ibepe & Pawpaw & Tree & Leaves \\
\hline Chasmantheran dependens & Menispermaceae & Ato & Chasmanthera & Tree & $\begin{array}{l}\text { Leaves, roots, } \\
\text { barks }\end{array}$ \\
\hline Citrulus lanatus & Cucurbitaceae & Egusi bara & Water melon & Herb & Fruits, leaves \\
\hline Citrus aurentifolia & Rutaceae & Osan wewe & Lime & Tree & Fruits, leaves \\
\hline
\end{tabular}


Kadiri et al

Journal of Drug Delivery \& Therapeutics. 2015; 5(3):24-32

\begin{tabular}{|c|c|c|c|c|c|}
\hline Cocos nucifera & Palmea & Agbon & Coconut & Tree & $\begin{array}{l}\text { Fruits, leaves, } \\
\text { barks }\end{array}$ \\
\hline Cola nitida & Steculiaceae & Obi & Kola & Tree & $\begin{array}{c}\text { Fruits, barks, } \\
\text { leaves }\end{array}$ \\
\hline Corchorus olitorius & Malvaceae & Ewedu & Jute & Herb & Whole plant \\
\hline Daucus carota & Aplaceae & Caroti & Carrot & Vegetable & Fruits \\
\hline Entandrophragma cylindrium & Meliaceae & Ijebo & Stave wood & Tree & Barks \\
\hline Euphorbia hirta & Euphorbiaceae & Emile & Asthma plant & Herb & Whole plant \\
\hline Ficus capensis & Moraceae & Opoto & $\begin{array}{l}\text { African mustard } \\
\text { tree }\end{array}$ & Tree & Leaves, Roots \\
\hline Ficus exasperate & Moraceae & Epin & Sand paper & Herb & Leaves \\
\hline Garcina cola & Guttiferaceae & Orogbo & Bitter cola & Tree & Fruits, Barks \\
\hline Gongronema latifolia & Asclepiadaceae & Madunmaro & Amaranth globe & Herb & Roots \\
\hline Gossypium barbadense & Malvaceae & Kere wu & Cotton seed & Shrub & Seeds \\
\hline Hibiscus sabbdariffa & Malvaceae & Sapa & Zobo & Shrub & Leaves \\
\hline Ipomoea batatas & Convolvulaceae & Odunkun & Sweet potato & Herb & Leaves \\
\hline Jatropha curcas & Euphorbiaceae & Lapalapa & Physic nut & Shrub & Leaves, Roots \\
\hline Khaya ivorensis & Meliaceae & Oganwo & $\begin{array}{l}\text { African } \\
\text { mahogany }\end{array}$ & Tree & Barks, Roots \\
\hline Kigelia Africana & Bignoniaceae & Pandoro & Sausage tree & Tree & Leaves \\
\hline Lantana camara & Verbanaceae & Ewo agogo & Bush lantana & Herb & Whole plant \\
\hline Mangifera indica & Anacadiace & Mongoro & Mango & Tree & Leaves, barks \\
\hline Mimosa prudica & Mimosaceae & Patonmo & Sensitive leaf & Herb & Whole plant \\
\hline Momordica charanta & Cucurbitaceae & Ejirin wewe & Bitter gourd & Climber & Leaves \\
\hline Morinda lucida & Rubiaceae & Oruwo & Brimstone tree & Tree & leaves, barks \\
\hline Musa specie & Musaceae & Ogede & Plantain & Shrub & Fruits \\
\hline Nicotiana tabacum & Solanaceae & Taba tutu & Tobacco & Shrub & Leaves \\
\hline Ocimum gratissimum & Lamiaceae & Efirin & Scent leaf & Herb & Leaves \\
\hline Parkia biglobosa & Leguminosaceae & Igba & Locust bean & Tree & Leaves \\
\hline Petveria alliaeae & Phytolaccaceae & Awogba & Guinea hen weed & Herb & Leaves, Roots \\
\hline Solanum melongena & Solanaceae & Igba & Garden gg & Herb & Leaves, Roots \\
\hline Talinum triangulae & Talinaceae & Gbure & Water leaf & Herb & Whole plant \\
\hline Tamarindus indica & Fabaceae & Ajagbon & Tamarind & Tree & leaves, Roots \\
\hline Terminalia catapa & Combretaceae & Frutu & Indian almond & Tree & Leaves, Barks \\
\hline Theobroma cacao & Malvaceae & Coco & Cocoa & Shrub & Seeds, Leaves \\
\hline Vernonia amygadalina & Asteraceae & Ewuro & Bitter leaf & Shrub & Leaves \\
\hline Vitex doniana & Labiatae & Eru/Ori & $\begin{array}{l}\text { West african } \\
\text { plum }\end{array}$ & Tree & $\begin{array}{l}\text { Seeds, Leaves, } \\
\text { Fruits }\end{array}$ \\
\hline Xylopia aethopica & Annonaceae & Eeru & Ethiopian pepper & Tree & Fruits \\
\hline Zea mays & Poaceae & Agbado & Maize & Shrub & Seeds, Fruits \\
\hline Zingiber officinale & Zingiberaceae & Atale & Ginger & Herb & Rhizomes \\
\hline
\end{tabular}


Table 3: plant forms, method of application, Duration and Taste of the herbal preparation

\begin{tabular}{|l|l|l|l|}
\hline Variables & Frequency & $\begin{array}{l}\text { Percentage } \\
\text { frequency }\end{array}$ & Mode \\
\hline Plants forms & & & \\
\hline Dry plant & 13 & 13.7 & \\
\hline Freshly collected plant & 21 & 22.1 & \\
\hline Both dry and freshly collected plant & 61 & 64.2 & 64.2 \\
\hline Method of application & & & \\
\hline Oral application & 81 & 93.1 & 93.1 \\
\hline Cold bathing & 3 & 3.4 & \\
\hline Inhalation & 1 & 1.1 & \\
\hline Steam covering & 2 & 2.3 & \\
\hline $\begin{array}{l}\text { Duration of administration of herbal } \\
\text { preparation }\end{array}$ & & & 62.4 \\
\hline Once daily & 58 & 62.4 & \\
\hline 2-3 times daily & 27 & 29.0 & \\
\hline Uncountable & 8 & 8.6 & \\
\hline Taste of the herbal preparation & & & \\
\hline Bitter & 72 & 72.0 & \\
\hline Sour & 23 & 23.0 & \\
\hline Sweet & 5 & 5.0 & \\
\hline Symptoms & & & \\
\hline Edema & 4 & 6.3 & \\
\hline Excessive sweating (fever) & 14 & 21.9 & \\
\hline Fatigue and loss of appetite & 1 & 1.6 & \\
\hline Excessive urination & 1 & 1.6 & \\
\hline Constant coughing & 44 & 68.8 & \\
\hline & & & \\
\hline
\end{tabular}

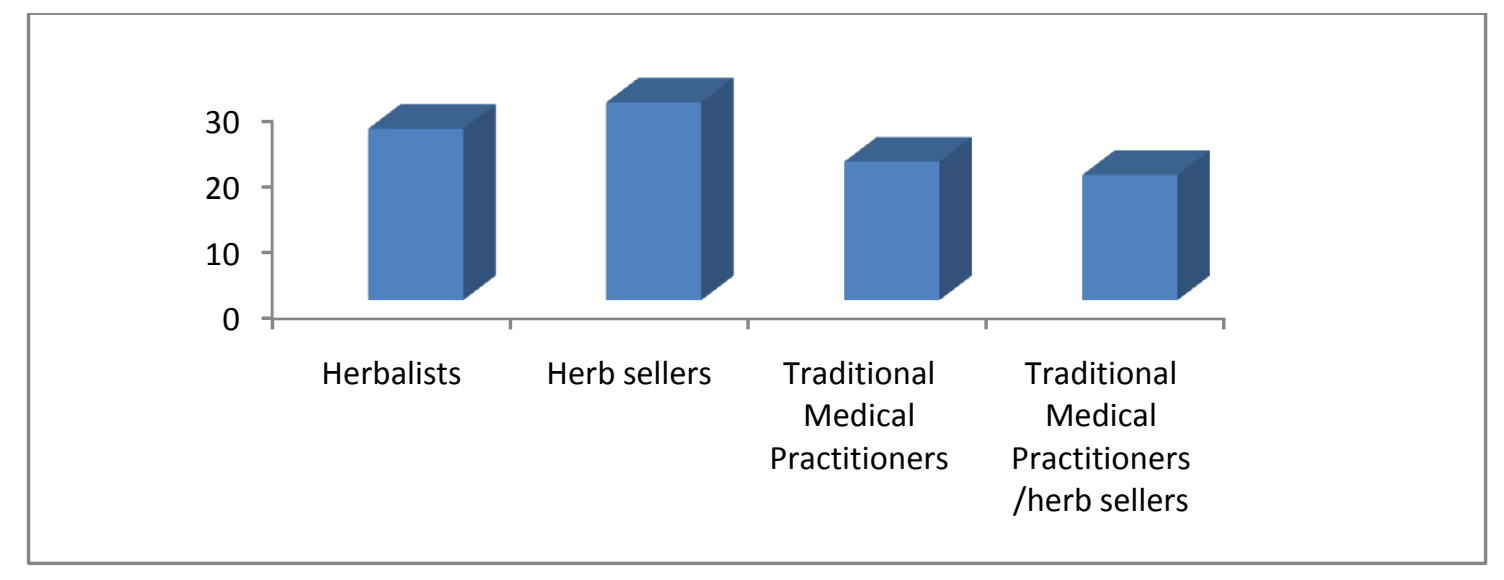

Figure 1: Categories of respondents

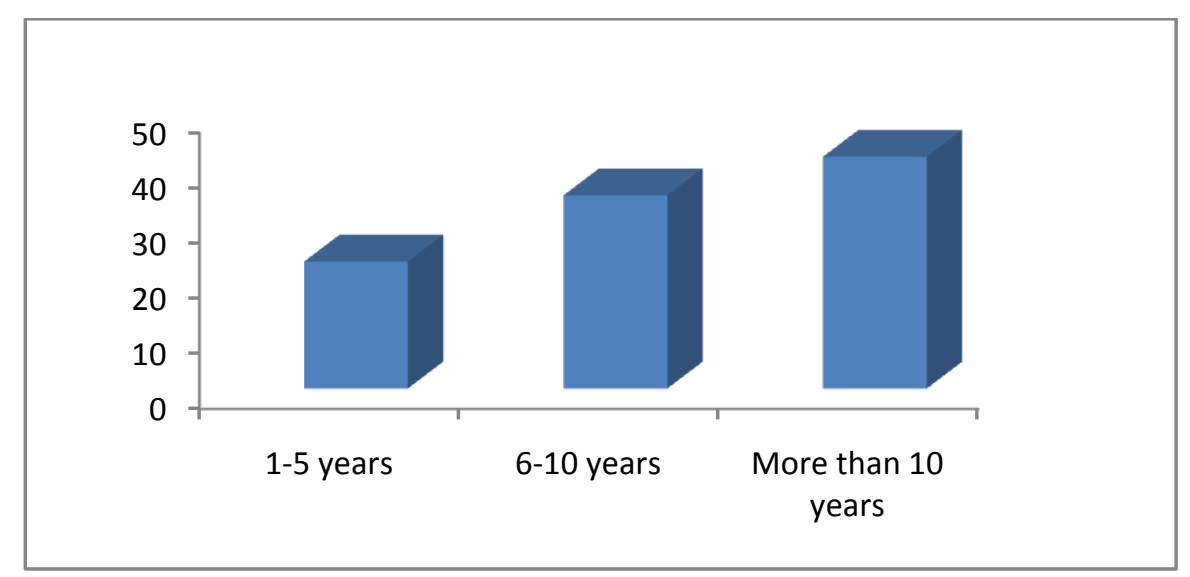

Figure 2: Category of years of herbal experience of the respondents. 


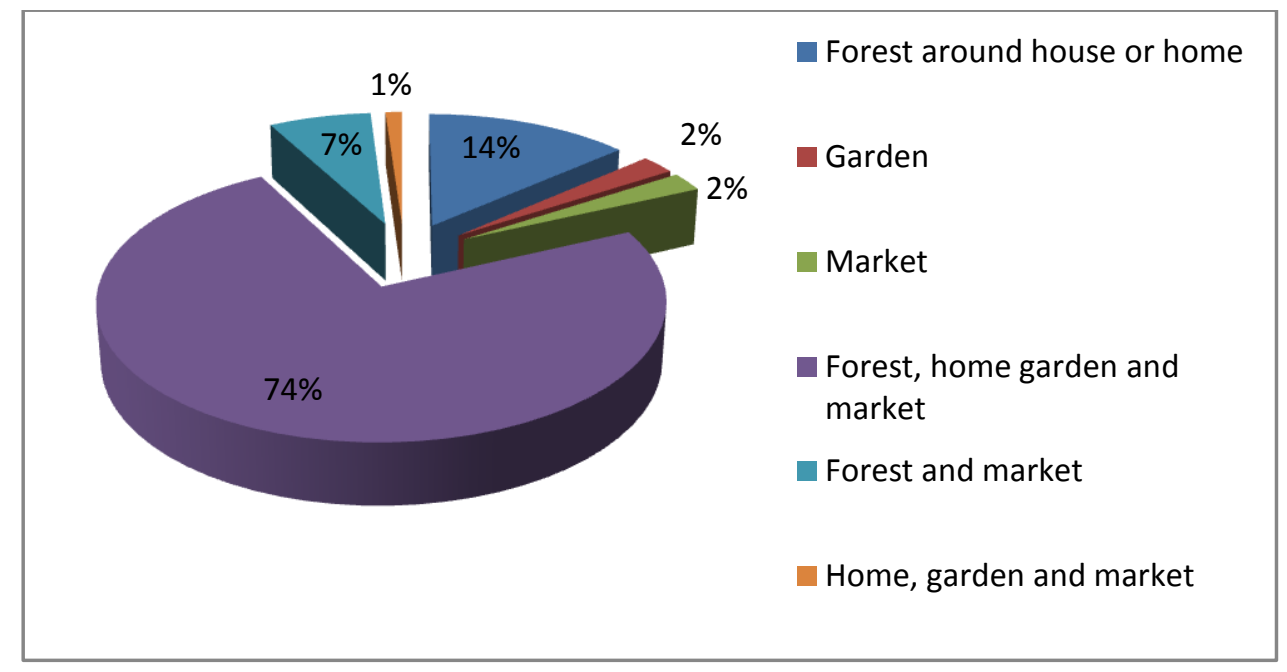

Figure 3: Place of availability of plant collated.

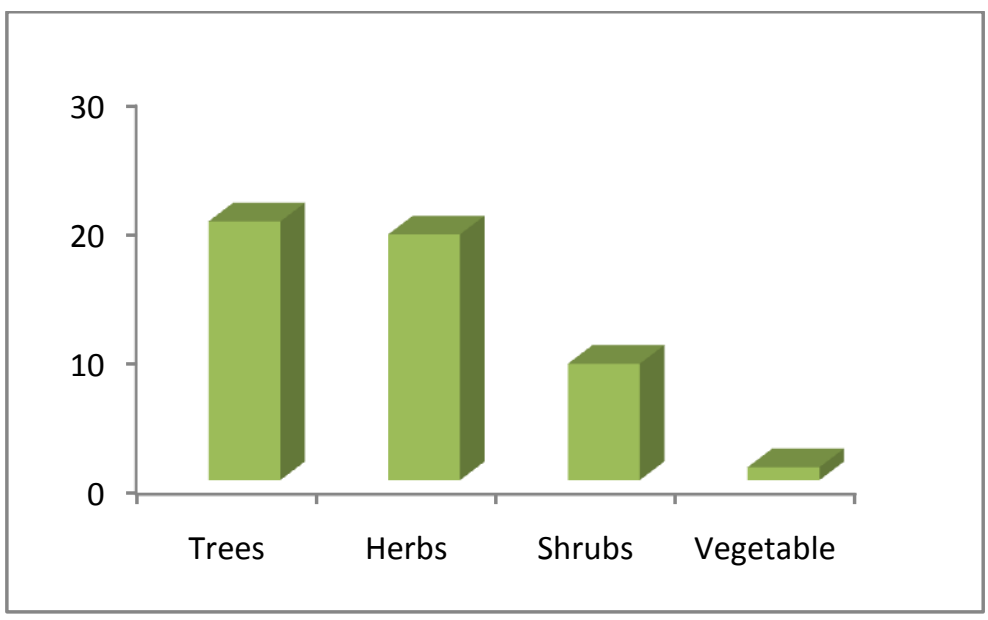

Figure 4: Habit of plants collated

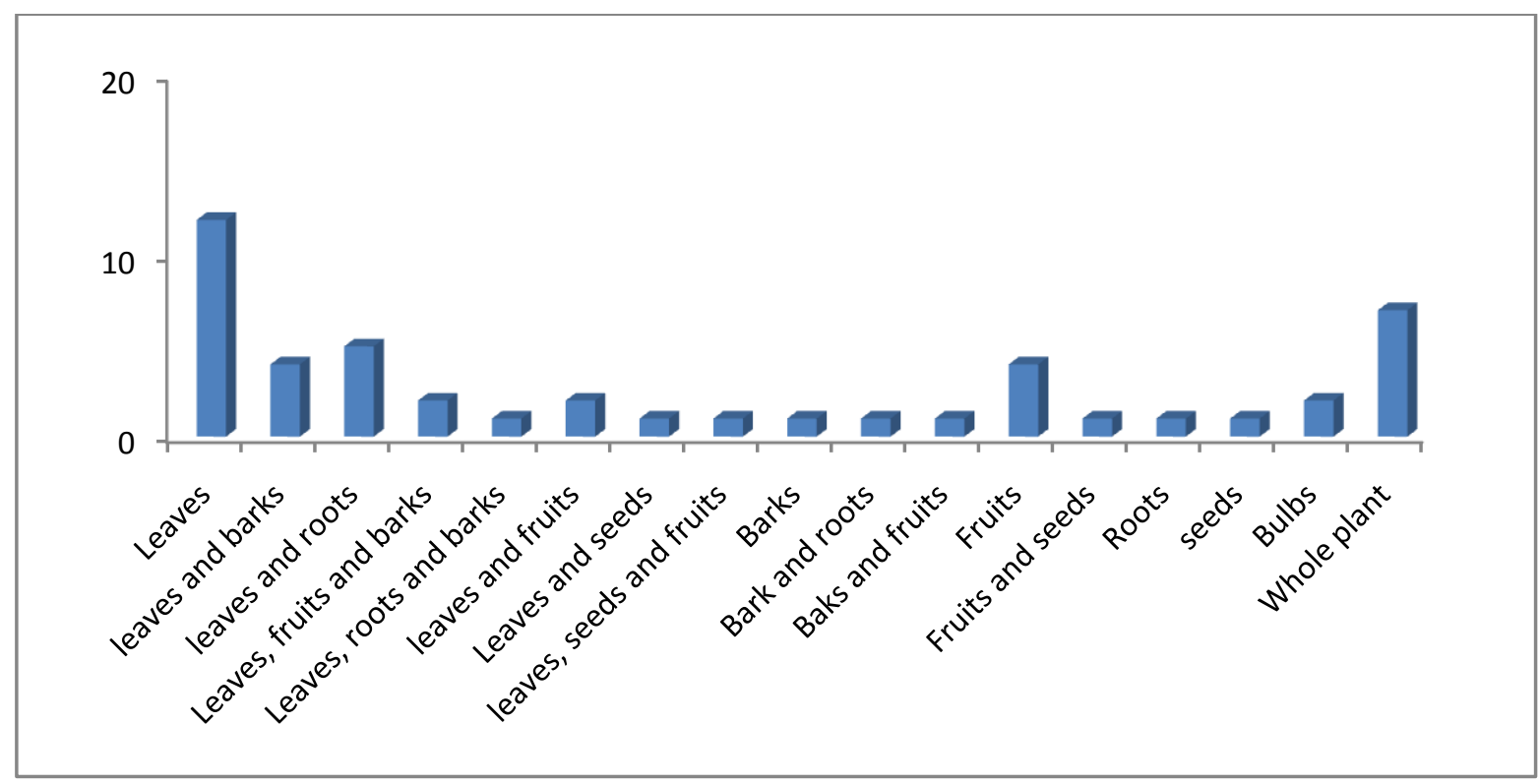

Figure 5: plants parts commonly used. 


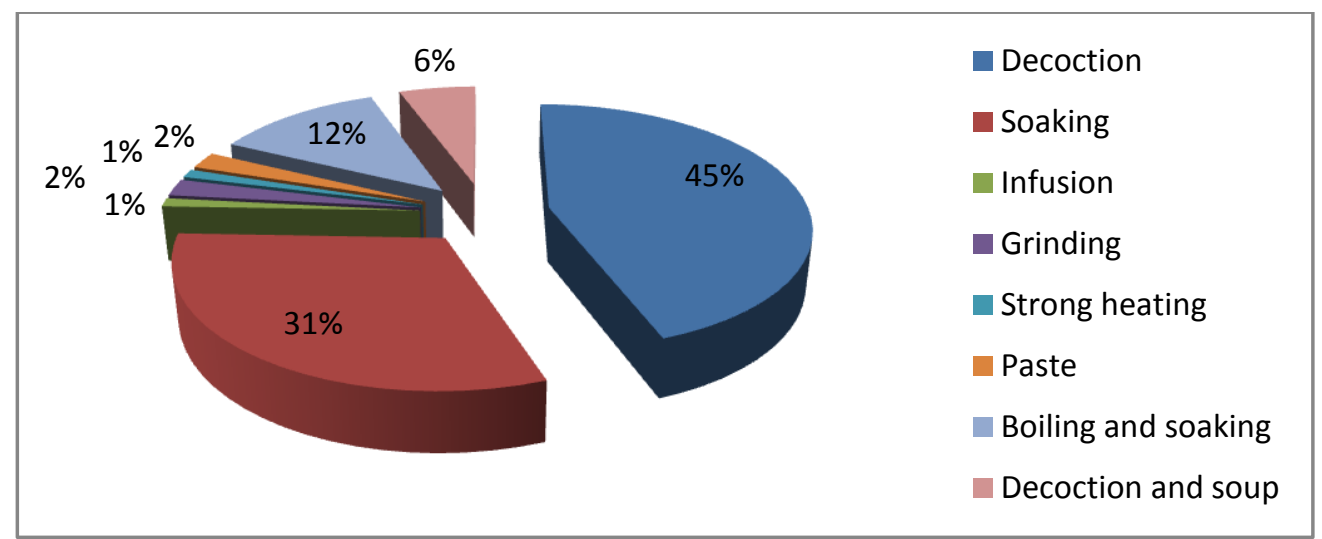

Figure 6: Method of preparation from the plants collated

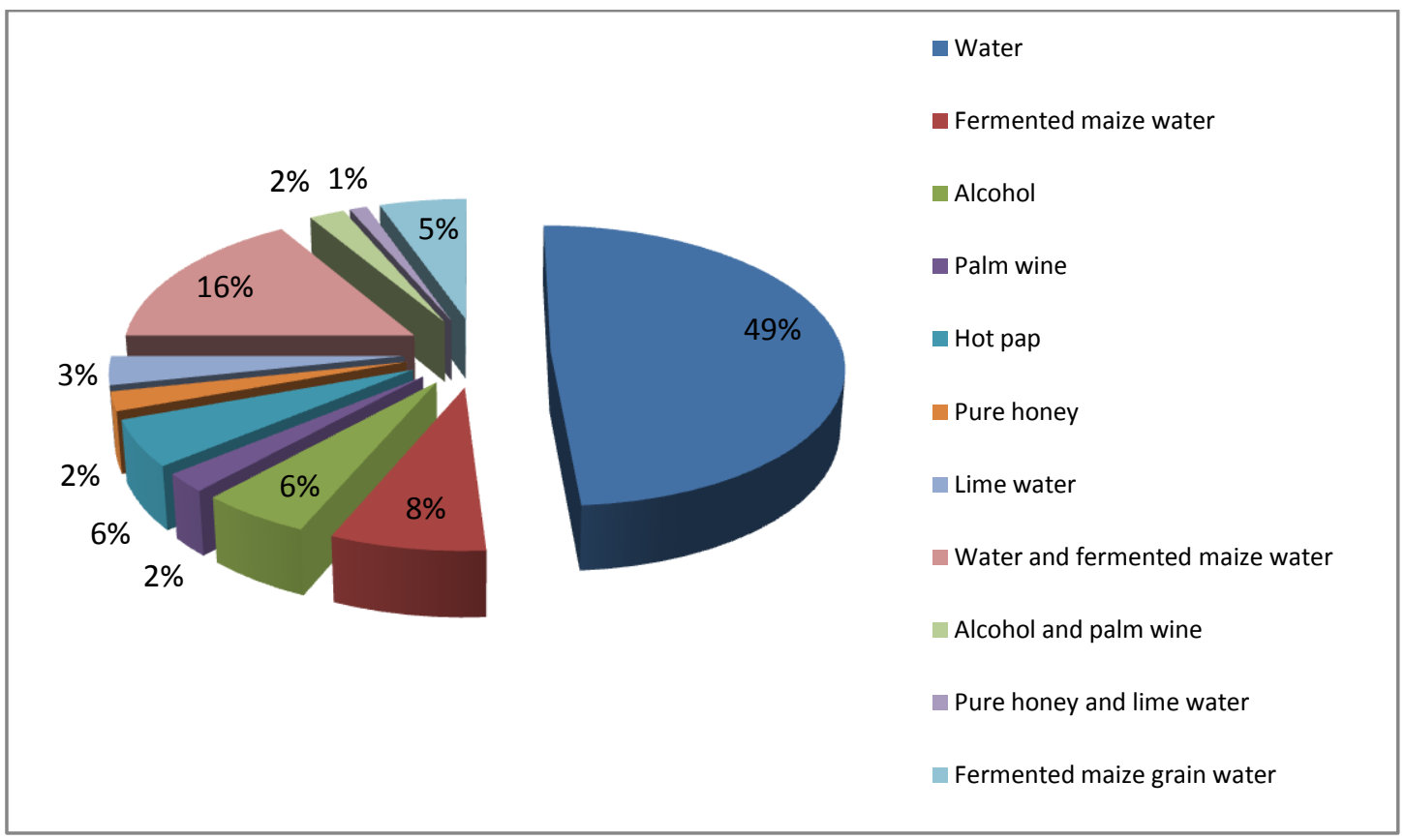

Figure 7: Solvent of choice

Table 4: Anti-nutrient content of leaves and root of plants commonly used for kidney and liver diseases in Odeda communities Abeokuta, Ogun State.

\begin{tabular}{|l|l|l|l|l|l|}
\hline \multirow{2}{*}{ Plants } & \multicolumn{4}{|l|}{ Anti-nutrient contents of leaves of plants commonly used for kidney and liver diseases } \\
\cline { 2 - 6 } & Phytate & Oxalate & Polyphenol \% & Cyanide & Tannins \\
\hline Leaf & & & & & \\
\hline Chasmantheran dependens & $3.75 \pm 1.25^{\mathrm{f}}$ & $7.00 \pm 2.35^{\mathrm{bc}}$ & $6.00 \pm 0.10^{\mathrm{c}}$ & $2.00 \pm 1.10^{\mathrm{bc}}$ & $16.00 \pm 0.11^{\mathrm{a}}$ \\
\hline Khaya ivorensis & $10.33 \pm 0.33^{\mathrm{b}}$ & $7.00 \pm 1.00^{\mathrm{bc}}$ & $7.6667 \pm 0.67^{\mathrm{b}}$ & $2.00 \pm 0.02^{\mathrm{bc}}$ & $14.67 \pm 0.13^{\mathrm{b}}$ \\
\hline Kigelia Africana & $11.00 \pm 0.58^{\mathrm{b}}$ & $6.00 \pm 0.58^{\mathrm{bcd}}$ & $5.00 \pm 0.02 \mathrm{~d}$ & $2.67 \pm 0.33^{\mathrm{b}}$ & $10.6667 \pm 0.33^{\mathrm{e}}$ \\
\hline Azadirachta indica & $13.00 \pm 0.00^{\mathrm{a}}$ & $9.00 \pm 0.58^{\mathrm{b}}$ & $7.3333 \pm 0.33 \mathrm{~b}$ & $2.33 \pm 0.33^{\mathrm{b}}$ & $13.3333 \pm 0.30^{\mathrm{c}}$ \\
\hline Ficus exasperate & $11.33 \pm 0.33^{\mathrm{ab}}$ & $12.33 \pm 0.33^{\mathrm{a}}$ & $9.00 \pm 0.58 \mathrm{a}$ & $4.33 \pm 0.67^{\mathrm{a}}$ & $12.3333 \pm 0.13^{\mathrm{d}}$ \\
\hline Root & & & & & \\
\hline Chasmantheran dependens & $7.96 \pm 0.01^{\mathrm{c}}$ & $2.53 \pm 0.01^{\mathrm{e}}$ & $3.00 \pm 0.01^{\mathrm{f}}$ & $1.07 \pm 0.01^{\mathrm{d}}$ & $2.63 \pm 0.08^{\mathrm{f}}$ \\
\hline Khaya ivorensis & $6.15 \pm 0.01^{\mathrm{de}}$ & $3.17 \pm 0.03^{\mathrm{de}}$ & $4.00 \pm 0.04^{\mathrm{e}}$ & $0.83 \pm 0.08^{\mathrm{d}}$ & $2.12 \pm 0.01^{\mathrm{h}}$ \\
\hline Kigelia Africana & $8.07 \pm 0.03^{\mathrm{c}}$ & $1.59 \pm 0.06^{\mathrm{e}}$ & $2.00 \pm 0.10^{\mathrm{g}}$ & $1.37 \pm 0.01^{\mathrm{cd}}$ & $1.64 \pm 0.58^{\mathrm{h}}$ \\
\hline Azadirachta indica & $7.68 \pm 0.02^{\mathrm{cd}}$ & $2.17 \pm 0.00^{\mathrm{e}}$ & $1.00 \pm 0.05^{\mathrm{h}}$ & $1.03 \pm 0.01^{\mathrm{d}}$ & $2.92 \pm 0.01^{\mathrm{f}}$ \\
\hline Ficus exasperate & $5.05 \pm 0.03^{\text {ef }}$ & $4.57 \pm 0.02^{\mathrm{cde}}$ & $2.00 \pm 0.12^{\mathrm{g}}$ & $1.167 \pm 0.23^{\mathrm{d}}$ & $3.12 \pm 0.67^{\mathrm{f}}$ \\
\hline
\end{tabular}

Means followed by different letters on the same columns are significantly different according to Duncan's Multiple Range Test at $p<0.05$. 


\section{DISCUSSION}

Traditional use of flora by local communities reveals the cultural heritage and biodynamic elements that have immense chemotherapeutic values to cure many diseases (Vo Van Minh, 2014). The cultural and biological diversity of Odeda and its environs offers immense opportunities for ethno-botanical studies for the health care delivery of people in the communities.

Majority of the local people are neglected and their basic health requirement is at the expense of nature which is at their proximity. People rely largely on medicinal plants found in their localities for their common ailments by traditional methods. This has made the trend of using medicinal plants common in old inhabitants than young people (Qureshi et al., 2013; Irum et al., 2014). Decrease of ethnopharmacological practices is due to encroaching industrialization and modern cultural changes in the life style. Documentation of indigenous knowledge about the use of plants for kidney and liver herbal remedies in Odeda is of paramount importance before the information is lost.

The observation that malvaceae and meliaceae are the most frequently mentioned families could be a pointer that the families could be scientifically investigated for management of liver and kidney herbal remedies.

Leaves were the most commonly used plants part for the control and management of the ailments. This could be because leaves are sites where many medicinal compounds such as alkaloids, tannins, coumarines, flavonoids, essential oils and inulins which are active components of most herbal preparations in high concentrations are synthesized and stored via photosynthesis. These compounds have been reported to give relief to patients suffering from kidney diseases and other diseases affecting both internal and external organs of man (Okigbo and Igwe, 2007; Ramesh and Okigbo, 2008). These results are clear indications that aerial parts of plants play important roles in herbal medicine preparation. The result of this finding could be a clears indication of wide use of leaves for herbal medicine compared to other plant part in the study area or importance of leaves for survival of the plants and animals (VoVan Minh, 2014). Utilization of the root and bulb highly affects the survival and ecological aspect of the plant because Medicinal plants are mostly harvested from the wild sources either for local use or trade purposes. This observation concurs with the finding of De-la-Cruz et al. 2007.

Most of the remedies were made from varying combination of two or more plants and parts.

The use of combination of plants and plant parts to prepare remedy for ailments could be as a result of additive or synergistic effects of all the plants in use (Bussman and Sharon, 2006). Igoli et al. (2005) reported that the joint use of multiple medicinal plants in concoctions could be due to synergistic effects of phytocemicals. Although occasionally, the preparations are administered by inhalation application but the most common mode of administration was oral because most preparations are made with water as a solvent. Various plant parts were also mixed with oil, honey, milk or tea for enhancing their acceptability and medicinal properties. This observation is in agreement with report of Kadiri et al., 2014 who claimed that for effective treatment of catarrh and arthritis, small quantities of oil are added to the paste prepared by crushing the plant parts and that addition of oil might be to enhance the efficacy of the herbal remedies. The observation that although the respondents claimed the medicinal potential of the plants but could not explain their mode actions calls for further investigation about these plants.

Some of the anti-nutrients recorded in this study have been reported to have different implications on humans and their diets. Omoyeni and. Adeyeye (2009) reported that tannins posses anti-nutritional effect on the proximate composition by precipitating dietary proteins and digestive proteins and digestive enzymes to form complexes which are not readily digestible.

The anti-anti- nutrient contents of leaves and roots of Chasmantheran dependens, Khaya ivorensis, Kigelia Africana, Azadirachta indica and Ficus exasperate investigated contains low

level of anti-nutrients. This observation corroborates that reported by Omoyeni et al.,2012.

Anti-nutrient content of the leaves are capable of limiting the wide use of many plants as food due to their ubiquitous occurrence and deleterious effect on consumers . Some of these anti-nutrients can be reduced by different Heat methods of herbal preparation such as decoction and cooking, for example, boiling can reduce the soluble oxalate content of a food, if the water used for boiling is discarded thus, making the food prepared from these accessions safe for human consumption.

Finding of Miller et al.(1980) revealed that antinutrient content of plants in many cases vary due to variety and/or cultivar, climate condition, location, type of soil and season of the year during which they are grown.

However, consumption of different anti- nutrient such tannin, and saponins have also been encouraged despite their deleterious effect because they have been evaluated to be characterized by beneficial hypocholesterolaemic and hypoglycemic properties (Cheeke et al., 1978 ; Ojewumi and kadiri, 20014). This study therefore recommends that preparation should be taken inform of decoction because of the belief that heating has reduction effect on the antinutrient levels of plants

\section{CONCLUSION}

This survey shows the flora values of the study area and need for herbal enlightment on the use of herbs as an alternative medicine. There is also need for further herbal research to remove some herbal impediments on indigenous methods of treating kidney and liver disease. 


\section{REFERENCES}

(1) Swati Shrivastava Kanungo V. K. Ethnobotanical Survey of Surguja District with Special Reference to Plants Used by Uraon Tribe in Treatment of Respiratory Diseases. International Journal of Herbal Medicine 2013; 1 (3): 131134

(2) Al-Adhroey A H, Nor ZM, Al-Mekhlafi H M, Mahmud R. Ethnobotanical study on some Malaysian anti-malarial plants: A community based survey. $J$. Ethnopharmacol.2010; 132: 362-364.

(3) Irum Naz, M. Ahmad, Tamoor-ul-Hassan. Ethnobotanical Investigation of Medicinal Flora used by Indigenous People in District Attock, Pakistan, J. Of Advanced Botany and Zoology 2014; Volume 1/ Issue 4

(4) Sofowora A. Medicinal Plants and Traditional Medicine in Africa, 2nd Edn., Spectrum Books Limited, Ibadan, Nigeria 1993; 1-153.

(5) Vo Van Minh, Nguyen, Phạm T K T. Medicinal plants used by the Hre community in the $\mathrm{Ba}$ to district of central Vietnam, Journal of Medicinal Plants Studies 2014; Vol. 2 Issue. 3: 64-71

(6) Qureshi R, Waheed A, Arshad M, Umbreen T. Medicoethnobotanical inventory of Tehsil Chakwal, Pakistan. Pak. J. Bot. 2009; 41(2): 529-538.

(7) Okigbo R N, Igwe D I. The antimicrobial effects of Piper guineese 'uziza' and Phyllanthus amarus 'ebe-benizo' on Candida albicans and Streptococcus faecalis. Acta Microbiologica et Immunologica. 2007; 54(4): 353-366.

(8) Ramesh P, Okigbo R.N. Effects of medicinal plant combinations as anti-infectives. Afr. J. Pharm. Pharmacol. 2008; 2(7): 130-135.
(9) De-la-Cruz H Vilcapoma G, Zevallos P A. Ethnobotanical study of medicinal plants used by the Andean people of Canta, Lima, Peru. J. Ethnopharmacol 2007 111: 284-294.

(10) Bussman RW, Sharon D. Traditional medicinal plant use in Northern Peru: tracking two thousand years of healing culture. J. Ethnobiol. Ethnomed., 2006; 2: 47

(11) Igoli J O, Ogaji O G, Tor-Anyiin T A, Igoli N P, Traditional medicine practice amongst the Igede people of Nigeria. Part II. Afr. J. Trad.CAM. 2005; 2(2): 134-152.

(12) Kadiri M., Ojewumi AW, Amuda A, Ogunderu OF, Fadimu OY Ethnobiological survey of indigenous flora used for management of catarrh and arthritis in Abeokuta. International Journal of Green and Herbal Chemistry 2014; 3(4): 1690-1704.

(13) Omoyeni O A, and Adeyeye E I. Chemical Composition, Calcium, Zinc and Phytate

(14) Interrelationships in Aerva lanata (Linn) Juss. Ex Schult Leaves, Oriental J. Chem., 2009; 25(3)

(15) Miller GA, Youngs V L, and Oplinger E S. Environmental and cultivar effect on oat phytic acid concentration. Cereal chemistry, 1980; 57: 189-191

(16) Cheeke P R., Pederson M W and England D C. Responses of Rats and Swines to Alfalfa Saponins. Can. J. Anim Sci., 1978;58, 783 .

(17) Ojewumi AW, and Kadiri M. Phytochemical screening and anti-diabetic properties of Terminalia schimperiana Leaves on rats, International Journal of Green and Herbal Chemistry, 2014 ; 3 (4):1679-1689. 